\title{
A Macroeconomic Taxation Model for an Islamic Economy
}

\author{
Muhammad Hussain
}

\section{INTRODUCTION}

Present day Islamic states are called for performing many functions like the ones stated by Siddiqi (1986). He has given a long list of functions, which are to be performed by the present day Islamic states. He has classified them into the following three broad categories:

1. Functions permanently assigned by Shariah.

2. Functions derived on the basis of Ijtihad ${ }^{1}$ for the present situation.

3. Functions assigned to the state by the people through the process of Shura (i.e. consultation).

Performance of these functions is only possible if enough resources are available to the present day Islamic states. Under the circumstances the present writer is of the view that for satisfying the revenue needs of the present day Islamic states, there is no way out except to resort to new taxes in addition to the traditional taxes. Some Muslim jurists of the medieval period of Islamic history especially AlGhazali (1937) and Al-Shatibi (1914) have, permitted that additional taxation can be resorted to if the needs, particularly the defence needs, of the state require so. Some Fuqaha [Al-Qardawi (1980)] have also laid down certain conditions for levying of additional taxes. These conditions are briefly stated below:

1. Intense Need:

The additional taxes can be levied on the rich only when there arises an intense need for which resources are not available and there must not be any other way out including borrowing, for financing that need.

2. Just and Equitable Distribution of the Tax Burden:

The burden of new taxes be equitably distributed, so that each group of the society should contribute in accordance with their ability to pay. The ability to pay from Islamic point of view means that overall taxes and tax

Muhammad Hussain is Professor and Director, School of Economics, International Institute of Islamic Economic, International Islamic University, Islamabad.

${ }^{1}$ Ijtihad can be defined as exertion of all possible effort to ascertain the command of Shariah for any given problem or situation. 
rates are such that the tax payers can easily pay them and they do not feel overburdened by the taxes. Keeping in view this constraint, the equals are required to pay taxes equally and unequals to pay unequally.

3. Proceeds to be Spent on the Promotion of the Interest of Ummah:

The proceeds of new taxes must be spent on 'Masalih Ummah' i.e. on the activities that promote the interest of Ummah as a whole and not on the provision of luxuries for the rulers.

4. Consultation with and Consent of the Ahl-al-Hal wa-al-Aqad from the Ummah:

New or additional taxes can only be levied after consultation with and consent of Ahl-al-Hal wa-al-Aqad i.e. the distinguished worldly wise and religiously knowledgeable persons, whose opinion is sought in all matters related to the affairs of Ummah. Muslim rulers, including all functionaries of the government like the finance ministers, cannot levy additional taxes of their own free will. They have to consult and abide by the advice given by 'Ashab al-Shurah' i.e. the persons, who must be consulted with and their advice must be sought in the affairs of Ummah.

In the view of the present writer above conditions for additional taxation, particularly second and fourth conditions, are mainly for ensuring justice in the sphere of taxation, which is the main concern of the Fuqaha. The traditional taxes, which are either based on 'Nas' (Quran and Sunnah) or 'Ijtihad' are levied at very low rates and fuqaha have urged Muslim rulers to levy taxes at such amounts and rates that tax-payers are easily able to bear and they do not feel overburdened by them. Fuqaha are so much concerned with justice in the sphere of taxation that in case of traditional taxes, they have even specified the just limits of tax rates. Ibn Najaim (n.d.) has pointed out that extreme upper limit for ability to pay in case of Kheraj (land tax) is fifty percent of the produce of land and he has stressed that a Muslim ruler cannot raise the rate beyond this limit because it is the upper limit of justice and Kheraj cannot be lowered below 20 percent of the produce of land, because it is considered to be the lower limit of justice.

Keeping in view Muslim Fuqaha's primary concern for justice in the sphere of taxation, a theoretical construct of a just tax rate ${ }^{2}$ is used in this paper to develop a macroeconomic taxation model, which is mainly based on the views regarding taxation as expressed by a great Muslim jurist, Imam Abu Yusuf, and a fourteenth

${ }^{2}$ Fuqaha have set some limits on tax rates keeping in view the requirements of justice to be done to the tax payers. Ibn Najaim has set upper limit of justice for Kheraj at 50 percent and lower limit at 20 percent of the produce of land. All tax rates based on 'Nas' (Quran and Sunnah) are considered to be just tax rates, e.g., 2.5 percent rate of zakah and 5 percent $u$ shr rate for the produce of irrigated ushri land and 10 percent of produce of rainfed ushri land are considered to be just rates. In this way Fuqaha have specified limits of just rates for different taxes. 
century renowned Muslim historian and economist, Ibn Khaldun (1980). The present writer has named this model as "Abu Yusuf-Ibn Khaldun Macroeconomic Taxation Model". The model is a long term model rather than being a short term one. Initially it is presented as mainly a supply side model. In the last part of the paper demand side is introduced into the model and basic analytics of explicit introduction of demand side to the model are dealt with.

\section{ABU YUSUF-IBN KHALDUN MACROECONOMIC TAXATION MODEL}

The main theme of this model is that just tax rates provide incentives for work and investment and thus justice attracts Barakah (blessing and growth) from Allah, and as a result economic growth takes place in the economy at a very high rate. Consequently tax revenues of the state go on rising. Because a constraint of justice is imposed on an Islamic state, it would stop short of optimising tax revenues. On the contrary very high tax rates which are indicative of injustice and oppression would prove to be disincentive for work and investment. Moreover, injustice and oppression exerted to the people would result in causing the Barakah to vanish and output of the economy would decline, and as a result total tax revenue would decline.

With a view to supporting the above theme of the model some excerpts from the writings of Imam Abu Yusuf and Ibn Khaldun are first presented and then the model is graphically developed and explained.

Imam Abu Yusuf (1979) has stated in his book Kitab-al-Kheraj "Justice and equity with oppressed and refraining from oppression, in addition to the reward in the hereafter, bring about increase in tax revenues, and thereby the prosperity of the towns enhances. The Barakah (blessing and growth) is dependent upon justice and it vanishes with oppression. Tax revenues collected through oppression would harm the towns and destroy them."

In order to capture Ibn Khaldun's philosophy of taxation the following excerpts from his Muqaddimah are presented here:

"It should be known that in the beginning of the dynasty, taxation yields a large revenue from small assessments. At the end of the dynasty, taxation yields a small revenue from large assessments.

The reason for this is that when the dynasty follows the ways (sunan) of the religion, it imposes only such taxes as are stipulated by the religious law, such as charity taxes, the land tax, and the poll tax. They all have fixed limits that cannot be overstepped ....... When tax assessments and imposts upon the subjects are low, the people have the energy and desire to do things. Enterprises grow and increase, because the low taxes bring satisfaction. When economic enterprises grow and increase, the number of individual imposts and assessments mounts. In consequence, the tax revenue, which is the sum total (of the individual assessments) increases. 
When the dynasty continues in power, their revenue needs become more varied because of prosperity and luxury in which they are immersed ........ As a result the individual imposts and assessments upon the subjects, agricultural labourers, farmers and all other tax payers increase. Every individual impost and assessment is greatly increased, in order to obtain a higher tax revenue ........ Eventually, the taxes will weigh heavily upon the subjects and overburden them

The assessments increase beyond the limits of equity. The result is that the interest of the subjects in economic enterprises disappears, since when they compare expenditures and taxes with their income and gain and see the little profit they make, they lose all hope. Therefore, many of them refrain from all economic activity. The result is that the total tax revenue goes down, as (the number of) the individual assessments goes down.

If (the reader) understands this, he will realise that the strongest incentive for economic activity is to lower as much as possible the amounts of individual imposts levied upon persons capable of undertaking economic enterprises. In this manner, such persons will be psychologically disposed to undertake them, because they can be confident of making a profit from them". 3

It is evident from the above excerpts that both Imam Abu Yusuf and Ibn Khaldun were of the view that a few taxes and lower tax rates coupled with justice would enhance the prosperity of the society because doing justice to people attracts Barakah from Allah. Consequently tax revenues would increase. Excessively high tax rates are indicative of injustice and as a result prosperity of the society is adversely affected. Consequently overall tax revenues of the state decline.

Using these ideas of Imam Abu Yusuf and Ibn Khaldun, a macroeconomic taxation model named after them is presented graphically in Figure 1. The graphical technique used in the model is adapted from Adams (1981).

In Part $\mathrm{A}$ of the Figure, it is assumed that a lower general (income) tax rate, $t_{1}$, is a just tax rate from Islamic point of view. We have also assumed a higher general (income) tax rate, $t_{2}$, which is indicative of injustice, and it is assumed to be an oppressive tax rate from the point of view of Shariah. In this part of the Figure, before tax real wage rate of workers, W/P, is measured along the vertical axis and level of employment, $\mathrm{N}$, is measured on the horizontal axis. A lower and just tax rate, $t_{1}$, provides incentive to work, at this tax rate the supply curve of labour is $S_{\mathrm{Nt1}}$.

A higher and oppressive tax rate, $t_{2}$, provides disincentive to work and as a result, the supply curve of labour shifts to $S_{\mathrm{N} 2}$. It should be noted that higher tax rates usually reduce the after tax real wage and cause the labour supply schedule to shift to the left according to modern supply side economists. But if higher tax rates are oppressive, as it is assumed here, then in the words of Ibn Khaldun (1980) "the interest of the subjects in economic enterprises disappears and they lose all hope. Therefore, many of them refrain from economic activity". As a

${ }^{3}$ These are excerpts from the translation of Ibn Khaldun's Muqaddimah by Franz Rosenthal. We have changed the word 'cultural' from the translation to the word 'economic'. As it was felt that this word truly represents the meaning of the given arabic text. 
result supply curve of labour will shift to the left as is shown by $S_{\mathrm{NE}}$ supply curve of labour.

Fig. 1.

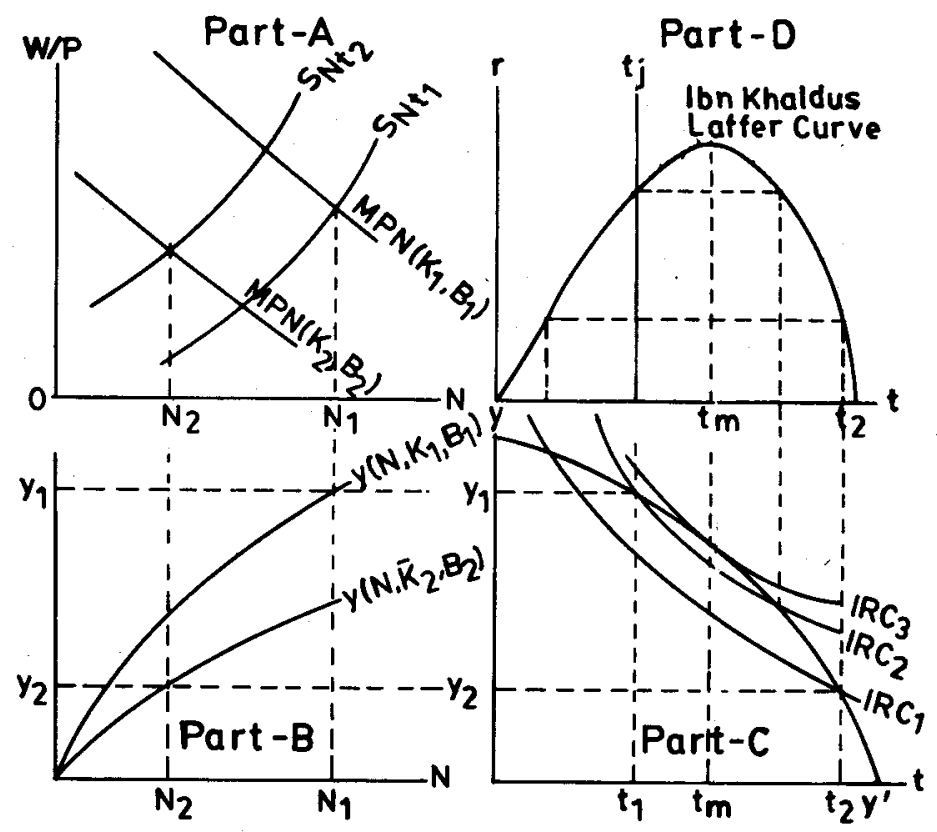

In Part $B$ of the Figure, the real output, $y$, is measured on the vertical axis and the employment level of labour, $\mathrm{N}$, on the horizontal axis. In this part, it is assumed that a just tax rate, $t_{1}$, would provide incentive to invest to investors, as a result workers will be working with a larger stock of capital shown by $\bar{K}_{1}$ (i.e. the stock of capital which will be forthcoming at $t_{1}$ ). Moreover, justice done to the people will result in attracting Barakah (blessing and growth) from Allah. It is assumed that Barakah can be indicated by the residual growth of output which can not be ascribed to any conventional factor of production. It is also assumed here that Barakah is like disembodied technological progress and it is falling like manna from heaven. The Barakah associated with $t_{1}$ is shown with $B_{1}$.

Thus Barakah coupled with larger capital accumulation will shift the aggregate production function of labour from $y\left(N, \bar{K}_{2}, B_{2}\right)$ to $y\left(N, \bar{K}, B_{1}\right)$. The aggregate production function of labour will shift upward with a just tax rate like $t_{1}$ and it will be depressed with an oppressive tax rate like $t_{2} \cdot \bar{K}_{2}$ is smaller stock of capital, which will be forthcoming at $t_{2}$, and $B_{2}$ is Barakah associated with $t_{2}$. As $t_{2}$ 
is assumed to be an oppressive tax, hence Barakah will vanish with it. From these production functions demand curves for labour, $\operatorname{MPN}\left(\overline{\mathrm{K}}_{1}, \mathrm{~B}_{1}\right)$ and $\operatorname{MPN}\left(\overline{\mathrm{K}}_{2}, \mathrm{~B}_{2}\right)$ are derived in Part $A$ of the Figure. Hence, in Part $A$ of the Figure, an equilibrium level of employment of $N_{1}$ is determined at tax rate $t_{1}$ and a level of $N_{2}$ is determined at an oppressive tax rate, $t_{2}$.

Keeping in view these employment levels in Part B of the Figure, output level will be $y_{1}$ at $N_{1}$ and $y_{2}$ at $N_{2}$.

In Part $C$ of the Figure, the relationship between different tax rates, $t_{1}$ and $t_{2}$, and different output levels like $y_{1}$ and $y_{2}$, is depicted with downward sloping yý curve, called the tax base response curve. This curve shows that output level would be higher at lower just tax rates and it would be lower at oppressive tax rates.

In Part $\mathrm{C}$ different Iso-Revenue Curves, $\mathrm{IRC}_{1}, \mathrm{IRC}_{2}$ and $\mathrm{IRC}_{3}$ are drawn. These curves are based on the idea that

$$
T=t y
$$

where $T$ indicates total tax yield and $t$ is the tax rate and $y$ is the output level. It should be noted that output, $y$, is used as a proxy tax base. It does not mean that the present writer is advocating for making income as a tax base for an Islamic state.

Equation (1) points out that total tax yield is the product of tax rate $(t)$ and level of output $(y)$, which is used as a proxy tax base here. If the total tax yield is held constant at a certain level, say $\bar{T}$ then,

$$
\bar{T}=t y
$$

will give us a rectangular hyperbola type of Iso-Revenue Curve. Three such IsoRevenue curves, $\mathrm{IRC}_{1}, \mathrm{IRC}_{2}, \mathrm{IRC}_{3}$ are drawn in Part $\mathrm{C}$. The intersection (or tangency) points of these curves with yý curve provide us with different tax yield $(T)$ levels, which are shown in Part D of the figure and as a result a parabolic curve is obtained, which is known as Khaldun-Laffer curve in economics literature. The present writer prefers to call this curve, Ibn Khaldun-Laffer curve. The optimum tax yield occurs at a tax rate, $t_{m}$ on this curve, and that is the tax rate at which $\mathrm{IRC}_{3}$ becomes tangent to yý curve.

A solid vertical line $t_{1} t_{j}$ is drawn at tax rate $t_{1}$ in Parts $C$ and $D$ of the Figure 1 , which shows that $t_{1}$ is the just tax rate, $t_{j}$, which cannot be transgressed by an Islamic state. As a result the parts of the Iso-Revenue curves lying to the right of this line are inoperative in an Islamic framework. Thus an Islamic state faces truncated Iso-Revenue curves and the truncated parts of the curves lie to the right of $t_{1} t_{j}$ line and these parts are not operative. Only parts of these curves lying to the left of line $t_{1} t_{j}$ are operative. Similarly the part of the Ibn Khaldun-Laffer curve lying to the right of line $t_{1} t_{j}$ is also inoperative because an Islamic state is not allowed to transgress the limits of justice. Thus deliberate efforts at optimisation of tax revenue 
are not compatible with Islamic spirit, if the limits of justice are violated. In other words, an Islamic state may stop short of maximising its tax revenues in order to preserve the limits of justice.

But that does not mean that in the pursuit of justice, Islamic state's tax revenues would suffer. Because justice will attract Barakah (blessing and growth) and as a result the revenues of the state would go on increasing as it happened during the reign of Umar Ibn Abd Al-Aziz (R.A.). He adopted a taxation structure which was based on Islamic justice and a result public revenues increased tremendously. Nadvi (1948) has reported the following saying of Umar Ibn Abd AlAziz, "May Allah curse Hajjaj Ibn Yusuf, he neither knew etiquette of Deen (religion) nor that of worldly affairs. Despite his excesses and injustice, he could not raise the revenue from Iraq more than 28 million Dinars and during my reign without resorting to any oppression and without doing any injustice, the revenues from Iraq went upto 124 million Dinars. If I lived longer, these revenues would go on increasing due to the justice we are doing to the people".

We would like to point out that western economists have ascribed to Ibn Khaldun some policies, which he would have never liked. Policy implications of Ibn Khaldun-Laffer curve, according to. the view of western economists are, that in order to achieve maximisation of tax revenue the government should go on increasing the tax rates if the elasticity of tax revenue with respect to tax rates (i.e. $\Delta T|T| \Delta t \mid t)$ is less than 1 , and if it is greater than 1 , it should go on decreasing tax rates in order to optimise its tax revenue. Ibn Khaldun was mainly concerned with equity and justice with the people, he would have never approved a tax revenue optimisation policy, which is devoid of justice to the people.

\section{ABU YUSUF-IBN KHALDUN MACROECONOMIC TAXATION MODEL WITH DEMAND SIDE ADDED TO IT}

In this section an attempt is made to introduce the demand side to the supply side model of the preceding section. For this purpose we shall use the approach which was developed by Beck (1979). He has derived a new curve, which he calls YQ curve. This curve represents the supply side in a r, y space. We know that the demand side is usually represented by IS and LM curves and these curves are also drawn in $r, y$ space. For derivation of YQ curve representing supply side and IS and LM curves representing demand side, we shall use real rate of return or real profit rate in place of interest rate as a factor price for obtaining capital. In other words we shall consider it as a variable representing cost for obtaining funds for investment in an Islamic economy. This is the approach, which was adopted by Khan (1985), Haq and Mirakhor (1986). Haq and Mirakhor define profit rate or rate of return per unit of investment ( $r$ ) as

$$
r=\frac{\lambda \Pi^{*}}{\Gamma^{*}}
$$


where $\Gamma$ is the optimal level of investment in an enterprise, $\Pi^{*}$ is the optimal profit obtained from that level of investment and $\lambda$ is the profit sharing ratio. They conclude that, in the presence of certainty and competitive conditions, the investment demand schedule will be downward sloping in $r$ in an interest free Islamic economy. Defining $(r)$ this way results in derivation of IS and LM model similar to the one found in the intermediate macroeconomics text books.

Following Beck's approach the YQ curve representing the supply side can be derived from factor markets by assuming a Cobb-Douglas production function of the following form:

$$
y-N^{a} K^{1-a}
$$

where $N$ and $K$ are labour and capital inputs respectively. We assume that the supply curve of labour is upward sloping and workers are not subject to money illusion.

In Figure 2-b, it is shown that marginal product of capital (MPK) curve shifts

Fig. 2.

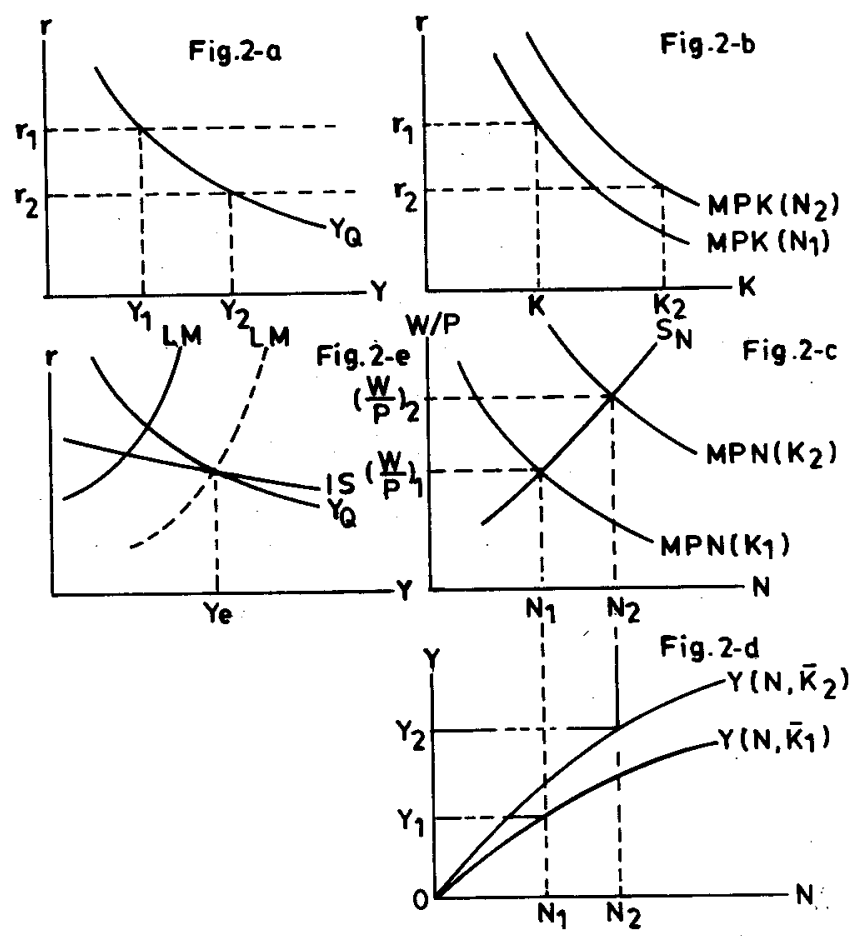


upward when employment level increases from $N_{1}$ to $N_{2}$. With $r_{1}$ and $N_{1}$ the equilibrium capital stock is $K_{1}$ and with $r_{2}$ and $N_{2}$ the equilibrium capital stock is $\mathrm{K}_{2}$. In Figure 2-c, marginal product of labour curve is MPN $\left(\mathrm{K}_{1}\right)$ with capital stock at $\mathrm{K}_{1}$ and $\mathrm{MPN}\left(\mathrm{K}_{2}\right)$ with capital stock at $\mathrm{K}_{2}$. In the labour market equilibrium occurs at $(\mathrm{W} / \mathrm{P})_{1}$ and $\mathrm{N}_{1}$ when $\mathrm{MPN}\left(\mathrm{K}_{1}\right)$ is the demand curve for labour and at $(\mathrm{W} / \mathrm{P})_{2}$ and $\mathrm{N}_{2}$ when MPN $\left(\mathrm{K}_{2}\right)$ is the demand curve for labour.

In Figure 2-d aggregate production is $y\left(N, \bar{K}_{1}\right)$ when $\bar{K}_{1}$ is the capital stock, which the labour is to work with. The aggregate production function is $y\left(N, \bar{K}_{1}\right)$ when $\bar{K}_{2}$ is the capital stock, which the labour is to work with. Income level is $y_{1}$ with employment level at $N_{1}$ and $y_{2}$ with employment level at $N_{2}$.

In Figure 2-a, by showing supply of output $y_{1}$ at $r_{1}$ and supply of output, $y_{2}$ at $r_{2}$, YQ curve is obtained in $r, y$ space. This curve represents supply side in the $r, y$ space, while intersection of IS and LM curves represents aggregate demand in the same r, y space.

The YQ curve will be downward sloping when supply curve of labour is vertical or upward sloping. When supply curve of labour is perfectly elastic the YQ curve will be horizontal line. For the sake of ensuring stability of equilibrium of demand and supply sides, it is assumed that the YQ curve is steeper than the IS curve.

Following Mohsin Khan's approach in an interest Free Islamic economy IS curve can be represented by:

$$
y=c[y-t(y)]+i(r)+g \text { where } 0<C^{\prime}<1 \text { and } i^{\prime}<0
$$

LM curve can be represented by:

$$
M / P=m=l(r)+k(y) \text { where } l<0 \text { and } k^{\prime}>0
$$

where $r$ represents real profit rate, which represents the cost of acquiring investment funds in a profit and loss sharing system. In the money market this real rate of profit represents opportunity cost of holding idle money. The proportion of wealth held in the form of idle money is assumed to be negatively related to the real profit rate.

In the above equations all variables and symbols other than $r$ have the same meaning as in any standard macroeconomics text book and particularly Branson (1989). Small letters represent real values of the variables, while capital letters represent nominal values of the variables.

In Figure 2-e IS and LM curves are added to the YQ curve of Figure 2-a. If all the three curves had intersected at a single point that point would have represented the equilibrium of aggregate demand and aggregate supply at the given price level. But in our figure the YQ curve intersects the IS curve to the right of 
intersection point of the IS and LM curves. This shows that at the given price level aggregate supply is greater than the aggregate demand. Consequently price level will decline and LM curve will shift to the right until all the three curves intersect at a single point.

Now we are ready to add demand side to our supply side macroeconomic taxation model of Figure 1. This is done in an eight parts Figure 3.

Figures 3-a and 3-b are the same as Parts $B$ and $A$ of Figure 1. In Figure 3-c now equilibrium stock of capital is $K_{1}$ with $N_{1}$ level of employment, which prevails in the labour market with $t_{1}$ and Barakah associated with it, $B_{1}$. It is $K_{2}$ with $N_{2}$ level of employment, which prevails in the labour market with $\mathrm{t}_{2}$, and $\mathrm{B}_{2}$, Barakah associated with it. In Figure 3-d the curve $Y Q_{t 1}$ is the $Y Q$ curve associated with $t_{1}$ and the $Y Q_{12}$ is the $Y Q$ curve associated with $t_{2}$.

Fig. 3.
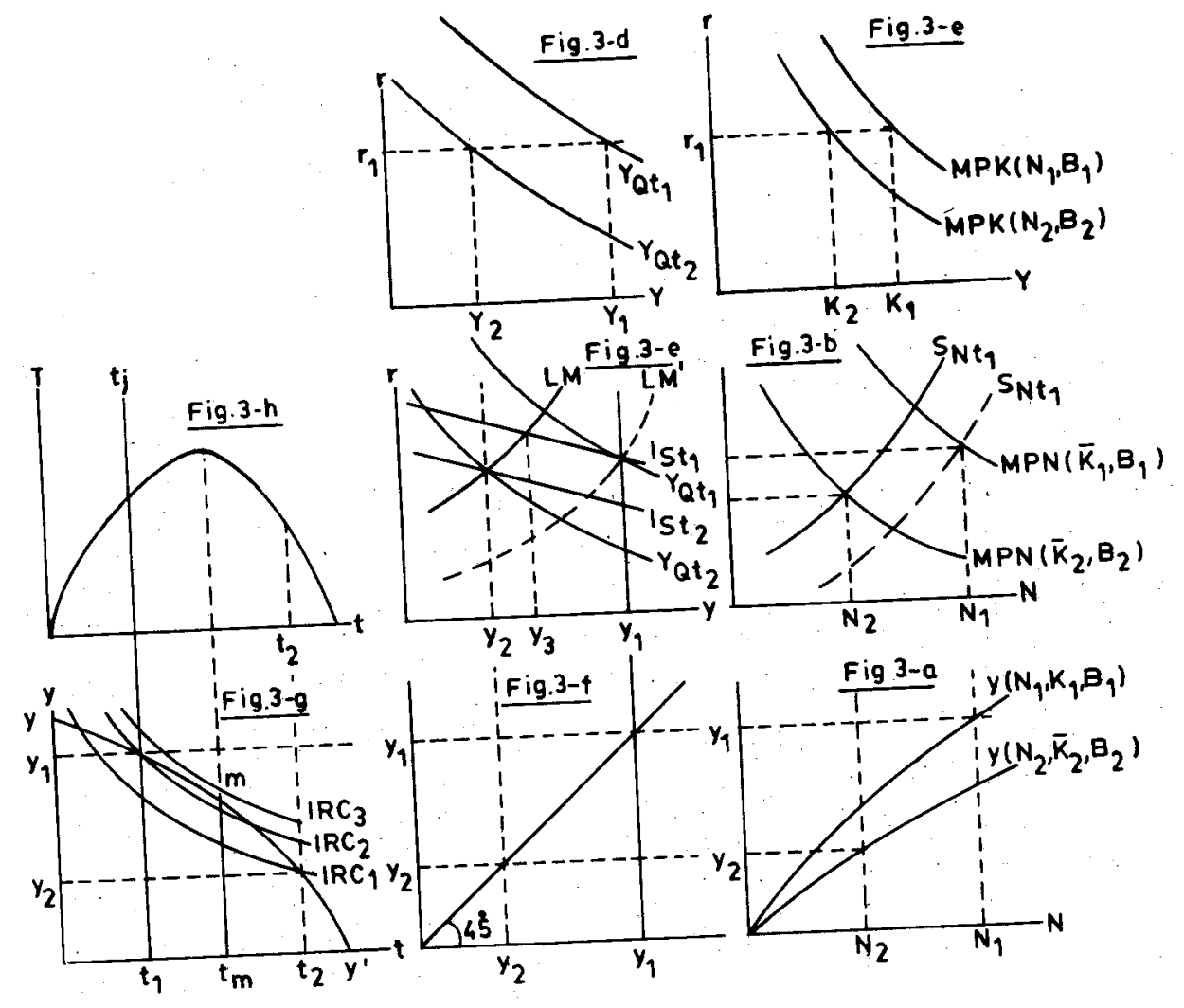

In Figure 3-e IS $_{t 1}$ is IS curve associated with $t_{1}$ and IS $_{n}$ is the IS curve associated with $t_{2}$ and $L M$ curve is added to the $Y Q$ curves of the Figure 3-d. In the 
figure $I S_{12}$ and $L M$ and $Y Q_{12}$ intersect at income level of $y_{2}$ at which the aggregate demand is equal to the aggregate supply. As a result of a tax rate cut on the demand side IS curve shifts to IS $\mathrm{t}_{\mathrm{tl}}$ and aggregate demand now is given by $y_{3}$ while aggregate supply associated with $t_{1}$ is given by $y_{1}$. As aggregate supply. is greater than aggregate demand, consequently price level will fall and LM curve will shift to the right until all the three curves, $\mathrm{IS}_{\mathrm{t} 1}, \mathrm{LM}$ and $\mathrm{YQt}_{\mathrm{l}}$, intersect at a single point, where income level is $\mathbf{y}_{1}$.

The Multiplier effect of the tax rate cut from $t_{2}$ to $t_{1}$ on the demand side is equal to $y_{2}-y_{3}$, when the supply side is considered, then this effect increases from $y_{2}$ $-y_{3}$ to $y_{2}-y_{1}$. In Figure 3-f the horizontal quantity axis of Figure 3-e is transferred onto the vertical axis. With the help of Figure 3-f, tax base response curve yý is derived in Figure 3-g. Figure 3-g and Figure 3-h are the same as parts $C$ and D of Figure 1.

\section{RELEVANCE OF THE MODEL FOR PRACTICAL SITUATIONS}

An attempt is made in this paper to represent the views on taxation of Imam Abu Yusuf and Ibn Khaldun in the form of a model using the economists' tools and jargons. Basically it is a theoretical model. Practical implications of this model for Islamic states are that they should always observe justice in the sphere of taxation. In case there is need for new taxes they should levy only such taxes and impose such tax rates as the subjects of a state are in a position to easily bear. They should not overburden the people with excessive taxes and oppressive rates.

\section{REFERENCES}

Abu Yusuf, Yaqub Ibn Ibrahim (1979) Kitab Al-Kheraj. Beirut, Lebanon: Dar-alMaarfah.

Adams, Roy D. (1981) Tax Rates and Tax Collections: The Basic Analytics of Khaldun-Laffer Curves. Public Finance Quarterly 9:4 415-430. (October).

Al-Ghazali, Muhammad Ibn Muhammad (1937) Al-Mustasfa. Vol. I. Egypt: AlMaktaba al-Tijariah al-Kubra. 142.

Al-Qardawi, Yousuf (1980) Figh al Zakat. Vol. II. Beirut, Lebanon: Moassasat-urRisalah. 1089-1098.

Al-Shatibi, Abu Ishaq Ibrahim (1914) Al-Eatisam. Vol. II. Egypt: Maktaba alMinar. 295.

Beck, John H. (1979) An Analysis of the Supply-Side Effects of Tax Cuts in An ISLM Model. National Tax Journal December.

Branson, William H. (1989) Macroeconomic Theory and Policy. Singapore: Harper and Row Publishers.

Haq, Nadeem ul, and Abbas Mirakhor (1986) Optimal Profit-Sharing Contracts and Investment in An Interest-Free Islamic Economy. Publish in Mohsin S. Khan and Abbas Mirakhor (eds) Theoretical Studies in Islamic Banking and Finance. Houston, Texas: The Institute for Research and Islamic Studies, 1987. 
Ibn Khaldun (1980) The Muqaddimah. Vol 2. Translated from Arabic by Franz Rosentheal. Princeton, N. J.: Princeton University Press.

Ibn Najaim, Zain-ud-Din (n.d.) Al-Bahr-al-Raiq Sharh Kanz al-Daqaiq.Vol. 5. Quetta: Al-Maktaba-al-Majidia. 107-108.

Khan, Mohsin S. (1986) Islamic Interest-Free Banking: A Theoretical Analysis. IMF Staff Papers. March.

Nadvi, Shah Moeen-ud-Din (1948) Tarikh-e-lslam (History of Islam) in Urdu. Vol.

2. Azam Garh, India: Maaraf Press. 214-215.

Siddiqi, Muhammad Nejatullah (1986) Public Expenditure in An Islamic State.

Presented at the International Seminar on Fiscal Policy and Development

Planning held at Islamabad during July 6-10 under the auspices of International Institute of Islamic Economics. Islamabad: International Islamic University. 


\section{Comments on \\ "A Macroeconomic Taration Model for \\ an Islamic Economy"}

Development of a Macroeconomic Taxation Model is a worthwhile effort on the part of the author to bring to the forefront the important issues of justice and fairness in taxation in the developing economies of the Islamic states. Not much theoretical work on scientific lines seems to have been conducted so far in this field. The development and analysis of the subject matter takes an added dimension at the present time because governmental activities of spending and taxes have become the focus of criticism and scrutiny in the industrially advanced as well as developing countries.

The revenue needs of all modern economies including those of the Islamic countries are rapidly rising due to the spectacular growth of public spending. The main causes of increase in spending have been many: (a) maintaining an adequate system of national security, (b) providing social goods and services for rapidly growing population, (c) an increasing pace of urbanisation, (d) satisfying citizens' demand for economic security, and (e) inflation. Moreover, securing the objectives of correcting or alleviating the instability, inefficiency, and inequality which the market system usually fosters provides the basic rationale for public spending and taxes. The justification for an increase in the rate of taxation and levying of new taxes in an Islamic country is based on the criterion of "intense need", as the author argues. At the present time, because of high demand for development programmes and public goods, the need for public spending is rising. Islam promotes equity in the distribution of resources. Therefore, it sanctions that additional taxes should be levied on the well-to-do to meet the revenue needs of the state. The factors mentioned above are responsible for the increase in government spending, indeed, meet the criteria of "intense need" for higher tax rates and new taxes. The next issue then leads to the determination of and to meeting the criteria of "just and equitable distribution of the tax burdens". I believe the author should develop such criteria by integrating the Islamic codes with the market principles of "ability to pay principles" and "taxable capacity", including the marginal rate of taxation.

As for the adoption and application of the neo-classical macroeconomic model along with various recent techniques such as the "laffer curve", and the "supply-side" approach are concerned it does not contribute much to the significance of the author's model and analysis. Moreover, methods and analysis used should closely conform to a sound scientific approach and fundamental professional criteria rather than invoke divine intervention: the latter is present all the time, nonetheless. 
Justice and fairness in taxation is the central theme of this paper. It will certainly add to the substance of this paper's contribution if the author could develop a workable definition of "justice" in taxation, and devise and detail specific taxes yhich would be within the framework of Islamic tenets.

Saleem M. Khan

Bloomsburg University,

USA. 